Burial customs and the pollution of death in ancient Rome

\title{
BURIAL CUSTOMS AND THE POLLUTION OF DEATH IN ANCIENT ROME: PROCEDURES AND PARADOXES
}

\begin{abstract}
The Roman attitude towards the dead in the period spanning the end of the Republic and the high point of the Empire was determined mainly by religious views on the (im)mortality of the soul and the concept of the "pollution of death". Contamination through contact with the dead was thought to affect interpersonal relationships, interfere with official duties and prevent contact with the gods. However, considerations of hygiene relating to possible physical contamination also played a role. In this study the traditions relating to the correct preparation of the body and the subsequent funerary procedures leading up to inhumation or incineration are reviewed and the influence of social status is considered. Obvious paradoxes in the Roman attitude towards the dead are discussed, e.g. the contrast between the respect for the recently departed on the one hand, and the condoning of brutal executions and public blood sports on the other. These paradoxes can largely be explained as reflecting the very practical policies of legislators and priests for whom considerations of hygiene were a higher priority than cultural/religious views.
\end{abstract}

\section{INTRODUCTION}

The Roman approach to disposing of the dead in the Republican era and the early Empire (the period from approximately $250 \mathrm{BC}$ to AD 250) was determined in part by diverse cultural/religious beliefs in respect of the continued existence of the soul after death and the concept of the "pollution of death". In addition, procedure and legislation were strongly influenced by practical considerations of hygiene (Lindsay 2000:152-73; Cilliers 1993:2). This article will consider these issues as well as the sometimes paradoxical attitude in terms of which the deceased were treated with great respect, on the one hand, but brutal executions and blood sports were condoned as public spectacles, on the other. Although the scope of the discussion is limited to the situation in the city of Rome itself, the findings may be taken as generally valid for other Roman cities and areas during the period. 


\section{CULTURAL/RELIGIOUS CONSIDERATIONS}

Religious views concerning the continued existence or complete extinction of a specific component of man/woman (the soul) after death have always played a decisive role in the way in which the deceased are treated. In particular, the concept that such a soul may exert an influence (for good or ill) on the bereaved and on its descendants has been crucial to decisions on how to dispose of the remains of the dead. As one might expect, there was no uniform view on this issue in ancient Rome. Religious convictions altered over the centuries, and a complete spectrum of views obtained in Rome during the period under discussion, ranging from the idea that there was no life at all after death, to a secure conviction in the continued existence of the soul, as exemplified in particular by the Christian view (Hopkins 1983:226-33). Toynbee (1971:34-6) is of the opinion that, perhaps as a consequence of the notion of the manes (ancestral spirits) which had to be honoured, the vast majority of Roman citizens believed firmly in some form of life after death and therefore also in the need to ensure that the soul was satisfactorily freed from the dead body by means of the appropriate rituals. This conviction determined the nature of the funeral rites, which could involve burial or cremation. There was a widespread belief that an incomplete cremation or burial could condemn the soul to roam restlessly for eternity (Lindsay 2000:168). For example, the spirit of Emperor Caligula was said to have continued to torment the community for a lengthy period after his hasty, incomplete cremation (Suetonius, Caligula c.59). It was also said that Nero avoided the area of Misenum because the sound of trumpets and lamentation had been heard at the grave of his murdered mother Agrippina after her over-hasty interment (Tacitus, Annals XIV.10).

Apart from these religious considerations, the cultural view of the "pollution of death" strongly influenced the treatment of the dead (Lindsay 2000:152-73). As Bodel (2000:128-49) puts it, death was unclean for the Romans in both cultural and religious terms, and it contaminated the living. The contamination lasted for the duration of the mourning period (normally nine days), and could be ended only by means of a specific purification process. It was believed to have a negative effect on interpersonal relations, but also, and more dangerously, to bring about a temporary end to contact with the gods and 
Burial customs and the pollution of death in ancient Rome

even to imperil civic functions. Those who were polluted could not make sacrificial offerings or legally perform certain public offices (such as the opening of buildings) (Livy ii.8.7). It was therefore very important for priests (particularly the priest of Jupiter) and other spiritual leaders, as well as those in public office, not to be contaminated by contact with the dead. The contamination could be incurred by touch, and in the case of priests even by indirect contact, such as the sight of a dead person. Since beans were by some philosophical groups believed to house the souls of the dead, priests were not allowed to eat or even touch them; indeed, they were not even supposed to mention them (Pliny, Historia Naturalis xviii.118-9). Pontifical laws authorised certain exceptions, however, for instance in cases of death in the homes of priests or civic officers (Lindsay 2000:154). The deaths of pre-pubertal children were not traditionally seen as causing pollution, as long as the corpses were speedily buried or cremated by night (Lindsay 2000: 156). In times of war, the officers concerned could be indemnified from pollution by legislation (Dio Cassius lvi.31.3; Tacitus Annals i.62). The need to prevent contamination thus directly influenced the treatment of corpses and funeral rites. Among other things, it also meant that people in certain professions - including all members of the funeral industry (see below) and executioners - were regarded as permanently polluted and had to live in isolation (Bodel 2000:135-48).

The concept of the pollution of death was partly founded on religious belief, but from the outset it was also based on pragmatic considerations which saw the presence of death as having unhygienic implications (Bodel 2000:134, 148-9). In the course of time the regulations were less strictly applied and replaced by other measures. By the end of the $2^{\text {nd }}$ century AD the notion had been significantly weakened (Lindsay 2000:166, 169, 172-3).

\section{DEMOGRAPHICS, DEATH STATISTICS, AND THE LAW}

Researchers agree that the population of Rome at the end of the Republican period was approximately 750000 (including women and children) and that by the height of the Empire period, two centuries later, it had reached over a million. With the establishment of Con- 
stantinople as the Eastern capital in the $4^{\text {th }}$ century AD, the population of Rome decreased once more to less than half a million (Bodel 2000: 128-9; Robinson 1992:8). There has been much speculation about the average life expectancy of a Roman citizen at this time. Scheidel (2001:1-26) has recently concluded that the generally accepted figure of 20 to 30 years may be correct, but is difficult to prove with accuracy. Bodel (2000:129) considers the annual mortality rate to have been approximately 40 per 1000, which computes on average to 30000 a year, or 80 a day. It goes without saying that this was not a fixed average and that wars, famines and epidemic diseases in particular would have a periodic impact. We know, for example, that Rome was ravaged by severe epidemics in 208 and 205 BC, and again in 187 and 180 BC (Retief \& Cilliers 1999:17-23). During the early Empire period there were epidemics in 23-22 BC, 54 AD and 65 AD. Suetonius (Nero c.39.1) recorded 30000 deaths in the autumn of AD 65 alone. In AD 125 Italy was devastated by the Epidemic of Arosius, and 40 years later there was the catastrophic Antonine Epidemic (probably smallpox) which lasted for decades. In AD 189 a mortality rate of 2000 a day was reported (Retief \& Cilliers 1999:267-72).

The disposal of the dead was thus an ongoing problem in Rome. In the light of the ruling cultural/religious views, along with the strong pragmatism concerning hygiene, measures in this regard were governed by legislation. Some of the earliest ideas are to be found in the laws of the Twelve Tables (451-449 BC) (Düll 1971:56). In terms of these laws, it was only in exceptional cases (such as Vestal Virgins and the most prominent citizens) that burials or cremations could take place within the bounds of the city (the pomerium). Babies under four days old could be buried at home, however. Suitable areas for cemeteries were identified, but these were adapted as required in the course of time. Bodel (2000:148) contends that this legislation was based primarily on considerations of hygiene rather than religion. In the $2^{\text {nd }}$ century Hadrian forbade all cremations or burials within three kilometres of the city walls (Lindsay 2000:170).

Further legislation in the Twelve Tables on funerals forbade the excessive show of mourning, among other things. For example, women were not permitted to tear their cheeks with their fingernails (Düll 1971:58). Later laws also forbade the use of slave labour and myrrh 
Burial customs and the pollution of death in ancient Rome

in the embalming process, but this regulation was often contravened (Cicero, De legibus ii.24). However, periodic revision of legislation by the senate and by imperial decrees replaced these stipulations in the course of time (Lindsay 2000:169-72; Robinson 1992:124-6).

\section{THE FUNERAL INDUSTRY}

As has been indicated, efficient burial of the dead was regarded as very important in ancient Rome and the prescribed procedures were strictly adhered to. In order to accommodate the less well-to-do, funeral expenses were given priority over the deceased's other debts (Hope 2000: 106-7). Although the state was usually highly critical of the establishment of voluntary associations (viewing them as potential hot-beds of anti-state activism), it approved the establishment of burial societies (collegia) which provided for affordable, honourable burial by means of regular contributions. These were usually joined by the poorer people (tenuiores), slaves and emancipated slaves, as well as by tradesmen and business or religious groups. From time to time the familia within such a collegium would also hold social gatherings, often under the aegis of a wealthy patron. A flask of wine typically formed part of the admission fee (Hope 2000:107; Hopkins 1983:211-6).

A paradoxical situation developed, primarily due to the concept of the pollution of death, insofar as the undertakers and their assistants were shunned, even abominated by the population, as a consequence of their constant exposure to death (Horace, Saturae ii.16.19; Bodel 2000:135-44). They were probably paid for their services by the public health authority (Bodel 2000:140). They had to live outside the city walls, and thus the community of undertakers gradually found a home outside the Esquiline gate in the area of the Libitina forest (Bodel 2000:136). According to Plutarch (Numa c.12.1), Libitina was originally a goddess of funerals, and the forest was named after her as early as the $2^{\text {nd }}$ century BC. Funeral equipment such as shrouds, biers, incense and torches could be purchased there (Plutarch, Quaestiones Romanae c.23; Varro, De lingua Latina v.35; Martial x.97.2). At a later stage, undertakers were even referred to as libitinarii (Bodel 2000:136). 
While the specialisations within the funeral industry were subject to gradual change, the following groupings could be found in Rome during the period under discussion:

a) Undertakers (libitinarii) operated as main contractors from the time of Augustus, organising the removal of corpses from the streets, and the various functionaries to officiate at funerals without necessarily being personally involved (Bodel 2000:136). They typically wore black clothes and a hat, and for some inexplicable reason were not permitted to bath at night. Dissignatores (marshals for funeral cortèges, and ushers at funerals and other occasions) all developed from this group (Horace Epistulae i.7.6; Seneca De beneficiis vi.38.4). Although dissignatores and praecones (also acting as heralds and auctioneers) enjoyed a higher status than ordinary undertakers, the Tabula Heracleensis disqualified them all from holding public political office (Bodel 2000:140).

b) According to Bodel (2000:138) the name funerarii was used during the middle and late Empire periods to designate the various mortuary functionaries: pollinctores were responsible for the preparation of the body and for the face powder used to camouflage the changes brought about by death (Plautus, Poenulus 1.63); vespillones were bearers who transported the corpses of the indigent, usually by night (Lindsay 2000:166); fossores were grave-diggers (Catullus xxii.1011); ustores performed cremations (Cicero, Pro Milone c.33), and fabri sandapilarum manufactured coffins (Martial ii.61.3-4; Juvenal viii. 175-6).

c) Even in the early Republican era, female mourners (praeficae) officiated at the homes of the deceased (Varro, De lingua Latina vii. 70) and accompanied the cortège, along with musicians playing flutes (tibicines) (Cicero, De legibus ii.59) and horns (tubicines), as well as actors and dancers (Suetonius, Caesar c.84; Vespasianus c.19).

In terms of the Lex Libitinaria Puteolana, an undertaker also sometimes had to act as headsman (carnifex) at executions in the area outside the Esquiline gate which had been set aside for public executions (Bodel 2000:140). While the general population usually regarded funeral functionaries with varying degrees of disapproval, the executioner was a total social outcast and was abhorred for the work which 
Burial customs and the pollution of death in ancient Rome

he performed for the general good (Plautus, Pseudolus 1.332; Cicero, Pro Rabirio v.15).

\section{CEMETERIES: BURIAL AND CREMATION}

Laws and regulations proceeding from the Twelve Tables, based partly on cultural beliefs but progressively more on considerations of hygiene, forbade burial or cremation within the city walls (pomerium), and led over time to the establishment of loca religiosa (formal cemeteries) and loca publica (belonging to the populace at large) (Cicero, De legibus ii.58; Bodel 2000:134).

In the loca religiosa, often alongside main roads leading out of Rome (as may still be seen along the Via Appia), grave plots could be bought by families. An extensive range of graves, grave adornments, vaults and monuments, in accordance with the means of the purchasers, were erected in these areas, which became "show" areas, albeit with a consecrated, religious character (Toynbee 1971:48-50; Hope 2000:109-10). From the time of Augustus columbaria were also built here - vaults within which containers of ashes could be buried (especially those of the less well-to-do and the members of burial societies) (Hopkins 1983: 211-6; Bodel 2000:133-4). On the Campus Martius, also outside the pomerium, emperors and other distinguished people were buried in the Mausoleum of Augustus (Hope 2000:109; Toynbee 1971:48-50).

Although the proportions of the loca publica were not clearly defined, they included, among other areas, a district outside the Esquiline gate which even in the early Republican period had served as a cemetery for the indigent, beggars and unidentified corpses. Bodel (2000:129, 130) estimates that up to 1500 such corpses would be found annually on the streets of Rome, causing significant problems for the authorities. These cadavera (as opposed to corpora — corpses destined for burial) would often also have been savaged by dogs, wolves or birds of prey. Suetonius (Vespasianus c.5.5) writes that the Emperor Vespasian's meal was interrupted on one occasion by a dog dropping a human hand at his feet. These corpses (whose handling apparently did not incur the pollution of death) were initially dumped in open mass graves (puticuli) outside the Esquiline gate. When the graves were full, they would be covered with soil (Varro, De lingua Latina 5.25; Bodel 2000:130- 
1). Horace (Saturae i.8.8-16) describes such an extremely unhygienic area (called a "potter's field"), covered in bones, potsherds and other refuse. It is also known that the corpses of the executed and of other individuals denied burial (see below) would be openly dumped in this area, next to the locus for public executions on the sessorium (Bodel 2000:145). The crucified were also left to rot here on their crosses. In 40 BC Maecenas began to cover the area with soil, and Augustus finally converted the Esquiline cemetery district into gardens (Horace, Saturae i.8.8-16; Bodel 2000:133; Hope 2000:111). It is not known how the corpses of the indigent or the executed were dealt with after this. The suggestion that mass cremation was the solution is not generally accepted (Kyle 1998:169-70; Bodel 2000:133-4).

Desecration of graves was punishable by death, but was performed in exceptional cases by emperors and other leaders (Hope 2000:1225). Although a cemetery was officially regarded with respect and piety, it was also a socially marginal area which, according to Hope, would be occupied by layabouts, beggars, thieves and prostitutes, particularly by night. It was generally believed that witches and poisoners performed occult activities there at night, and that it was inhabited by evil spirits (Lucan, Pharsalia 11.511-2; Horace, Saturae i.8.23-50; Hope 2000:125).

From the $8^{\text {th }}$ century $\mathrm{BC}$ cremation was accepted alongside burial as an appropriate means of disposing of the dead. During the period under discussion it was, in fact, the preferred procedure, but by the end of the $1^{\text {st }}$ century burial had again surpassed it in popularity (Lindsay 2000:168; Toynbee 1971:33-42). In order to prevent fire damage, crematoria (ustrinae) were built outside the city walls, according to specific regulations. They were in all likelihood equipped to cremate a corpse completely in seven or eight hours. Mass cremation was also performed in communal crematoria (Bodel 2000:133). Plutarch (Quaestiones Convivales iii.4.2) notes that the cremators would include at least one female corpse with every ten males, since the fatter female tissue helped to raise the temperature. Personal possessions, and even pets, were sometimes cremated along with a deceased. It was the usual practice to force the eyelids open before cremation. A small fragment of the corpse (os resectum) was also removed for later burial. This usage apparently goes back to a traditional pontifical preference for burial over crema- 
Burial customs and the pollution of death in ancient Rome tion (Lindsay 2000:168). After the procedure, wine and a little soil would be cast over the remaining ashes (iniectio glebae) (Toynbee 1971: $48-50$ ), which were then usually placed in a special urn or leaden container for preservation at home or at the grave.

\section{DISPOSING OF THE DECEASED}

\subsection{Status}

For the average Roman, the ideal conclusion to a successful life was an honourable death, followed by a fitting burial and a heritage of pleasant memories (Lindsay 2000:168). As far as the burial was concerned, however, social status and the cause of death were determining factors. The typical procedure for the funerals of distinguished, prosperous Roman citizens is reasonably well documented, but we know less about the poorer sector of the population, while the tragic final disposal of the indigent has been discussed above.

Soldiers who died honourably on the field of battle were buried, where possible, in mass graves, or else cremated (funus militare) (Toynbee 1971:55). In a period of continuous warmongering, however, corpses rotting in the open fields were an everyday sight. Traitors, discredited leaders and others sentenced by the emperor of the day were often tortured and executed in public, while corpses were often exhibited on the Aventine Hill on the Scalae Gemoniae ("Steps of sorrow") leading to the River Tiber. Public desecration of corpses occurred, as in the case of Sejanus, the erstwhile confidante of Tiberius (Dio Cassius lviii. 11.1-6). Sometimes the remains would be thrown into the Tiber after being dragged through the streets on a hook, as in the case of Vitellius, one of the rulers of the Year of Four Emperors (AD 69) (Suetonius, Vitellius c.17). Such actions were based on the premise that they should be seen as justified posthumous punishment for misdeeds committed during life. In political power struggles, in particular, the conquerors often had their opponents beheaded and then watched or participated in their further mutilation. One of the best-known cases occurred in $43 \mathrm{BC}$ when Antony had Cicero beheaded and displayed his head and hands in the Forum, on the very rostrum from which he had made several speeches against him (Plutarch, Cicero c.49). Although 
we cannot be absolutely sure, it seems as if this type of behaviour was not seen as incurring the pollution of death (Bodel 2000:134, 148).

Then there were those who were denied burial, and whose corpses were left on the sessorium to the mercy of the wild animals and the weather. This category included suicides (especially those who had hanged themselves), criminals who had been publicly executed, and any others sentenced to such an end by the emperor. According to Hope (2000:116-20), certain classes of professionals were at times stigmatised as infames (shameful) and denied burial. These included prostitutes, actors, certain categories of undertakers and some gladiators, particularly the so-called contract gladiators (auctorati), who belonged to the higher echelons of society.

\subsection{Domestic preparations for the burial}

The ritual marking the passage between death and the hereafter began in the home of the deceased and was strongly influenced by the implications of the pollution of death. The scope of the ritual was determined by the social status and the cultural awareness of the family. The procedure described below would have been typical for Romans of the middle and upper classes.

The moment of death was traditionally signalled by a final sigh. The last words of the dying person carried much weight (cf. the exitus clarorum virorum which, as a type of "Abschiedsrede", formed a literary genre of its own) (Stauffer 1950: I. 33-5). The first step of the funus translaticium phase was for the deceased to be kissed by a near relative, to catch the escaping soul. Suetonius (Augustus c.xcix) writes that after Augustus's dying words to his wife Livia ("Live in remembrance of our marriage, and farewell"), she kissed him and he breathed his last. The eyes of the corpse would then be closed by a family member and the conclamatio would begin. This involved continuously calling the name of the deceased until the cremation or burial, in order to ensure that he or she was indeed dead and to indicate that the procedures for an appropriate burial, iusta sepultura, had been set in motion. The corpse would be lifted from the bed, rested on its knees for a while and then placed on the ground to be washed and perfumed by female relatives or pollinctores. If the body was to be embalmed - a practice somewhat 
Burial customs and the pollution of death in ancient Rome

alien to the Romans (Toynbee 1971:42) - this was also done by the female relatives. A coin was sometimes placed in the mouth as a fee for the mythological boatman Charon. The poor would then usually be wrapped in black cloth, but a white toga was preferable, if affordable (Juvenal iii.171-80). With the emphasis on ostentation, the body was also adorned with all the emblems or honours which the person had earned in life. Branches of the cypress or the mountain pine (picea montis) were driven into the ground at the front door as a warning that there was a corpse within the house (Pliny, Historia Naturalis xvi.40.139).

After this, the body lay in state (expositio) on a special funeral bed in the atrium of the residence, with the feet pointing towards the front door (Terence, Phormio 1.97), originally to indicate that the death had not been a violent one. Visitors and mourners would come to offer their condolences. Flowers would usually be placed around the corpse, incense burned and special torches lit. In wealthy families there would also be mourners (praeficae) and musicians (tibicines and tubicines). Lucian (De luctu 12-15) writes that such occasions were sometimes characterised by excessive mourning and self-inflicted injuries, despite the fact that such extremes were forbidden by the laws of the Twelve Tables (Düll 1971:58). Emotional behaviour was seen as totally inappropriate for men (Hopkins 1983:217). Praeficae and other female mourners would dress in black and wear their hair loose and sprinkled with ashes (cf. Tacitus, Annals iii.2 on the death of Germanicus).

\subsection{The funeral procession and the burial}

At the commencement of the pompa (funeral procession), usually on the second day after the death, the corpse would be carried out of the house (exsequiae) by invited friends. Both the scope and the destination of the pompa depended on the status of the deceased (Lindsay 2000: 164). In the case of state funerals of emperors and other dignitaries (which, according to Cicero [Orationes Philippicae ix.7], were paid for by the state), the procession often took on the nature of a carnival and the general public would accompany the cortège to the Forum Romanum (Toynbee 1971:55, 56; Lindsay 2000:164-5). Actors were traditionally hired to perform satyr dances along the way in order to scare away evil spirits, while people wearing wax masks (imagines) represented those of the deceased's ancestors who had held high office. In the time 


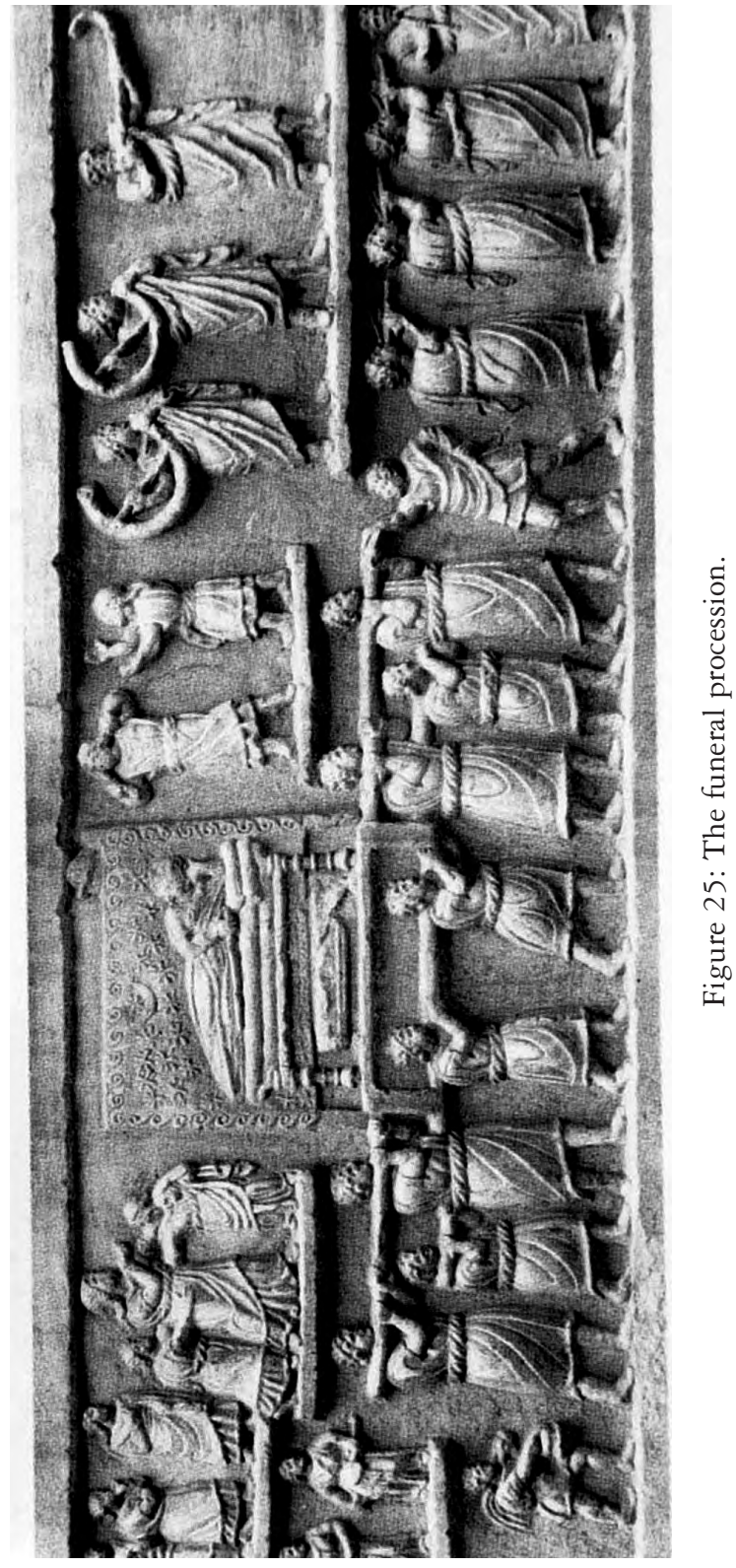


Burial customs and the pollution of death in ancient Rome

of Augustus the imagines were sometimes replaced by people carrying marble busts of the deceased (Toynbee 1971:46-8). Macabre mimes imitating the speech and lifestyle of the deceased were also performed by actors: Suetonius (Vespasianus c.xix) writes that the mimer Favor depicted Vespasian's miserliness during his funeral by asking the procurator how much the procession would cost and, on being told, enquiring if he could be thrown into the Tiber for a lesser fee. At the Forum the corpse would be placed in the centre and the eulogy (laudatio) performed at the rostrum, often by the oldest son (Suetonius, Caesar c.6). After Augustus's era, the scope of the pompa decreased and the eulogy in the Forum was replaced by a ceremony at the crematorium or the grave. The face of the deceased would then be covered (especially in cases of violent death, or if decomposition had already commenced) and the corpse would be borne on an open wooden stretcher to the grave or the crematorium (Apuleius, Metamorphoses iv.18; Dio Cassius lxi.7).

For the funerals of ordinary citizens, the pompa would progress directly to the cemetery or the crematorium. In the case of the wealthy, the bier (feretrum) would be carried by six to eight members of the family or friends dressed in black. The cortège was sometimes led by a dissignator and accompanied by paid musicians, or even praeficae. In the case of the poor, the coffin (sandapila) served as a bier, and was transported by four paid bearers (sandapilarii or vespillones). Slaves also often acted as bearers and would transport corpses by night (Martial viii.75). Special torches were carried on such occasions - to provide light, but also (in accordance with an old tradition) to keep evil spirits at bay (Lindsay 2000:155, 156).

At the grave or the crematorium there would be a short ceremony during which a little soil would be cast over the corpse. The os resectum would be removed (for later burial) before cremation (Varro, De lingua Latina v.23). A eulogy was sometimes spoken, followed by a final farewell, with a prayer that the earth should rest lightly upon the body. A compound of gypsum was traditionally strewn over the body before it was placed in a sarcophagus, coffin or vault (Toynbee 1971:48-54). Sometimes the bones would later be removed from the coffin or sarcophagus and kept in a smaller container or ossuarium (Bowker 1998:363). In later years Jews and Christians, in particular, were buried in catacombs or rock graves (bipogea). Those who could not afford coffins were 
buried in pits (fossae) in a lying or squatting position (Toynbee 1971: 48-50).

Toynbee (1971:61-4) also describes a specific Roman cult intended to pay continuous honour to the dead. It involved regular visits to the grave and feasts at which the deceased, too, was "fed" with gifts of food. Graves were provided with feeding tubes leading into the coffin, the sarcophagus or the urn containing the ashes and food and drink were periodically provided for the dead by this means. Particularly on the birthday of the deceased and the final day of the annual Festival of the Dead (Parentalia, 13-21 February) graves were visited, lamps lit and flowers (especially roses) presented. The Lemuria (9, 11 and 13 May) was also celebrated annually with midnight rites to relieve the hunger of the deceased and to appease any evil spirits.

\section{PURIFICATION PROCEDURES}

A specific purification ritual was prescribed by law to counteract what were believed to be the negative effects of the pollution of death. From the end of the $2^{\text {nd }}$ century $\mathrm{AD}$, however, these prescriptions progressively fell into disuse (Lindsay 2000:166-9).

It was the responsibility of the main beneficiary to ensure that the prescriptions for purification were followed. A funeral meal (silicernium) was to be eaten at the grave, and food and drink were to be left for the deceased. This offering would often be eaten by wandering indigents, with serious consequences in terms of the pollution of death (Cicero, De legibus ii.22.55; Aulus Gellius, Noctes Atticae xvi.4.4; Juvenal v.85).

All those who had taken part in the funeral had to purify themselves at home on the same day by means of the suffitio process, which involved being sprinkled with water from a laurel branch and passing under fire. The house had to be thoroughly swept with a special broom. The mourning period then commenced, to be ended on the ninth day with a feast at the grave (cena novendialis) and a libation for the spirits of the ancestors (manes) (Toynbee 1971:50-4). 
Burial customs and the pollution of death in ancient Rome

\section{PARADOXES}

It has been noted above that the treatment of the deceased in Rome during the period c. $250 \mathrm{BC}$ to $\mathrm{AD} 250$ was characterised by paradoxes. Priests, in particular, were seen as susceptible to the pollution of death even by means of eye contact with the dead, whereas ordinary citizens (as well as public officials) were free to enjoy watching blood sports in the arena. A whole cadre of professionals in the funeral industry was socially marginalised due to the fear of the pollution of death, but the general populace participated from time to time in the public humiliation and execution of those sentenced to death on the Scalae Gemoniae. A public official sentencing a citizen to death was merely doing his civic duty, and the execution itself was often a public spectacle (Hope 2000:112), but the executioner who had to carry out the sentence was demonised (Lindsay 2000:160).

Several of the customs were influenced by considerations of hygiene. Although the Romans' understanding of infectious contamination from decomposing corpses was primitive in comparison with modern medical knowledge, they had a very effective approach to sanitation and public hygiene. It was accepted that the practical realities of the pollution of death in an ongoing war situation had to be dealt with in a different way from those of everyday life. Lindsay (2000:156) has shown, for example, that officers leading armies were viewed as indemnified from any contamination by those who died in battle, and that the common soldier was not subject to the traditional purification procedures required after such pollution either. Views on the justified war (iusta bella) may have played a role in this regard. It was probably argued that brief exposure to the victims on the Scalae Gemoniae, or contact at a distance with the dead in the arena, posed less of a danger to the populace than the direct and continuous contact of undertakers with corpses, which was seen as incurring severe pollution.

The desecration of graves was punishable by death, but by drawing a distinction between loca religiosa and loca publica it was possible for Maecenas and Augustus to convert age-old cemeteries in the latter into public gardens. Formal graves and monuments around Rome were not normally desecrated. On occasion, however, the desecration of graves was justified by authority figures: Suetonius (Domitianus c.8) tells us, for 
example, that the emperor Domitian ordered a grave destroyed and the bones and ashes cast into the sea because it had been built with materials intended for the construction of a temple. After the civil war between Sulla and Marius the former had his opponent disinterred and his remains thrown into the River Anio (Pliny, Historia Naturalis vii.1.87; Cicero, De legibus ii.22.56-7). Suetonius (Augustus c.18) also writes that Augustus had the sarcophagus of Alexander the Great opened in order to place a golden crown respectfully on the mummy, but that Caligula did so in order to steal Alexander's breastplate (Suetonius, Caligula c.10).

The desecration of a corpse was also an offence punishable by death or by a life sentence to hard labour in the mines (Hope 2000:123), but the corpses of those sentenced to death were sometimes mutilated in public, as in the case of Cicero, whose decapitated head and hands were displayed in the Forum (Plutarch, Cicero c.49), or that of Brutus, whose head was thrown at the feet of Caesar's statue after the defeat of the conspirators in the civil war (Suetonius, Augustus c.13). Such desecrations were apparently acceptable, being seen as suitably extreme retribution for serious offences (Hope 2000:115).

The interesting ruling that pre-pubertal deaths did not cause pollution may have been related to the Roman understanding of the development of the soul and the view that young children are not full members of a family (familia) or community. The exemption of the corpses of the indigent, destined for the loca publica, from causing pollution, may have been simply a practical decision based on the fact that such corpses would be handled only by undertakers, who were regarded as contaminated in any case, and shunned on that account.

It thus seems that many of the paradoxes relating to the disposal of the dead can be explained by the pragmatic attitude of Roman legislators and priests, who developed a system focusing more on considerations of hygiene than on cultural/religious beliefs. Superstition did also play a role, however, and may have been the reason why those who had constant direct contact with the dead were socially marginalised. In wars and political power struggles, leaders were not deterred from the desecration of graves or corpses by the fear of death pollution. Nor did emperors such as the notorious Caligula and Domitian, who saw themselves as the equals of the gods, consider themselves bound by cultural/religious considerations with respect to the treatment of the dead. 


\section{Burial customs and the pollution of death in ancient Rome}

REFERENCES

\section{APUlEIUS}

1989. Metamorphoses. Vols. I and II (transl. J.A. Hanson). Cambridge MA: Harvard University Press. Loeb Classical Library.

\section{Aulus Gellius}

1927. Attic nights. Vols. I, II and III (transl. J.C. Rolfe). Cambridge MA: Harvard University Press. Loeb Classical Library.

\section{BODEL J}

2000. Dealing with the dead: undertakers, executioners and potter's fields in ancient Rome. In: V.M. Hope \& E. Marshall (eds.), Death and disease in the ancient city (London \& New York: Routledge), pp. 128-51.

BOWKER J

1998. The complete Bible handbook. London: Dorling Kindersley.

\section{Catullus}

1913. Poems (transl. F.W. Cornish). Cambridge MA: Harvard University Press. Loeb Classical Library.

\section{Cicero}

1926. Philippics (transl. W.C.A. Ker). Cambridge MA: Harvard University Press. Loeb Classical Library Vol. XV.

1927. Pro Lege Manilia. Pro Caecina. Pro Cluentio. Pro Rabirio (transl. H.G. Hodge). Cambridge MA: Harvard University Press.Loeb Classical Library Vol. IX.

1928. On the Republic. On the Laws (transl. C.W. Keyes). Cambridge MA: Harvard University Press. Loeb Classical Library Vol. XVI.

1931. Pro Milone et al. (transl. N.H. Watts). Cambridge MA: Harvard University Press. Loeb Classical Library Vol. XIV.

\section{Cilliers L}

1993. Public health in Roman legislation. Acta Classica 36:1-10.

\section{Dio CASSIUS}

1917. Roman history (transl. E. Cary). Cambridge MA: Harvard University Press. Loeb Classical Library Vol. VI.

\section{DÜLL R}

1971. Das Zwölftafelgesetz. Texte, Übersetzungen und Erläuterungen. München: E. Heimeran Verlag.

\section{Hope V M}

2000. Contempt and respect. In: V.M. Hope \& E. Marshall (eds.), Death and disease in the ancient city, London \& New York: Routledge, pp. 104-27.

\section{HOPKINS K}

1983. Death and renewal. Social studies in Roman history. Vol. II. Cambridge: Cambridge University Press. 


\section{HORACE}

1926. Satires. Epistles. The art of poetry (transl. H.R. Fairclough). Cambridge MA: Harvard University Press. Loeb Classical Library.

JUVENAL

1918. Satires (transl. G.G. Ramsay). Cambridge MA: Harvard University Press. Loeb Classical Library.

KYLE D G

1998. Spectacles of death in ancient Rome. London: Routledge.

\section{LINDSAY $\mathrm{H}$}

2000. Death-pollution and funerals in the city of Rome. In: V.M. Hope \& E. Marshall (eds.), Death and disease in the ancient city, London \& New York: Routledge, pp. 152-73.

LIVY

1919. History of Rome (transl. B.O. Foster). Cambridge MA: Harvard University Press. Loeb Classical Library.

\section{LUCAN}

1928. Pharsalia (transl. J.D. Duff). Cambridge MA: Harvard University Press. Loeb Classical Library.

MARTIAL

1993. Epigrams (transl. D.R. Shackleton-Bailey). Cambridge MA: Harvard University Press. Loeb Classical Library Vol. I.

PlaUTUS

1932. The little Carthaginian. Pseudolus. The rope (transl. P. Nixon). Cambridge MA: Harvard University Press. Loeb Classical Library.

\section{PLINY}

1938. Natural history (transl. H. Rackham). Cambridge MA: Harvard University Press. Loeb Classical Library Vol. I.

\section{PLUTARCH}

1914. Theseus and Romulus. Lycurgus and Numa, Solon and Publicola (transl. B. Perrin). Cambridge MA: Harvard University Press. Loeb Classical Library Vol. I. 1936. Roman questions et al. (transl. F.C. Babbitt). Moralia Vol. XVI. Cambridge MA: Harvard University Press. Loeb Classical Library.

\section{Retief F P \& Cilliers L}

1999. Epidemies in antieke Rome en ander Mediterreense lande. S.A. Tydskrif vir Natuurwetenskap en Tegniek 18(1):17-23.

1999. Epidemics of the Roman Empire, 27 BC-476 AD. S.A. Medical Journal 90(3):267-72.

\section{ROBINSON O F}

1992. Ancient Rome. London \& New York: Routledge. 
Burial customs and the pollution of death in ancient Rome

\section{SCHEIDEL W}

2001. Roman age structure: evidence and models. Journal of Roman Studies 91:126.

\section{SENECA}

1935. Moral essays: De Beneficiis (transl. J.W. Bassore). Cambridge MA: Harvard University Press. Loeb Classical Library.

STAUfFer E

1950. Abschiedsreden. In: F. J. Dölger et al. (Hrsg.), Reallexikon für Antike und

Christentum. Band I. Stuttgart: Hiersemann Verlagsbuchhandlung.

\section{SUETONIUS}

1998 and 1997. Lives of the Caesars (transl. J.C. Rolfe). Cambridge MA: Harvard University Press. Loeb Classical Library Vol I and II.

\section{TACITUS}

1931. Histories 4-5. Annals 1-3 (transl. C.H. Moore). Cambridge MA: Harvard University Press. Loeb Classical Library.

\section{TERENCE}

2001. Phormio. The mother-in-law. The brothers (transl. J. Barsby). Cambridge MA: Harvard University Press. Loeb Classical Library.

\section{TOYNBeE J M C}

1971. Death and burial in the Roman world. London: Thames \& Hudson.

\section{VARRO}

1938. On the Latin language (transl. R.G. Kent). Cambridge MA: Harvard University Press. Loeb Classical Library Vol. I. 